\title{
Sprawozdanie z Il obchodów „Dnia Informacji o Rekonstrukcjach Piersi BRA Day" w Łodzi
}

Pod koniec października 2015 roku w Łodzi odbyła się II edycja "Dnia Informacji o Rekonstrukcjach Piersi” w ramach międzynarodowej kampanii BRA Day (Breast Reconstruction Awareness Day). Była to kontynuacja inicjatywy z poprzedniego roku, kiedy to w Wojewódzkim Szpitalu Specjalistycznym im. M. Kopernika w Łodzi po raz pierwszy w Polsce zorganizowano „Dzień Informacji o Rekonstrukcjach Piersi". Zainteresowanie ze strony pacjentów, mediów i instytucji publicznych zachęciło organizatorów, aby również w 2015 roku przygotować podobną akcję. Podobną, ale nie taką samą, bo zorganizowaną na większą skalę. W organizację cyklu spotkań włączyły się bowiem: Dział Promocji Szpitala im. Kopernika pod wodzą Magdaleny Janus-Hibner, Fundacja „Pełną Piersią na Rzecz Rozwoju Rekonstrukcji Piersi" z prezes Magdaleną Kotlarczyk i Akademia Sztuk Pięknych, reprezentowana przez charyzmatyczną Małgorzatę Czudak. Nie sposób przy tym wymienić wszystkich osób, firm i instytucji, które wsparły inicjatywę organizacji BRA Day w Łodzi i pozwoliły tak wspaniale ją rozwinąć. Ale najważniejsze były panie, nasze pacjentki, które czynnie wzięły w niej udział. Pokazały, że rekonstrukcja piersi to nie tylko odbudowa „wyniosłości piersiowej”, ale również przywrócenie pewności siebie, kobiecości i radości życia.

W tym roku obchody BRA Day tradycyjnie rozpoczęły się w trzecią środę października wykładem dla Łódzkiego Oddziału Polskiego Towarzystwa Onkologicznego. Wykład o psychologicznych aspektach rekonstrukcji piersi przedstawiła mgr Ewa Pomorska z WSS im. Kopernika w Łodzi, która również przygotowała warsztaty dla pacjentów.

Następnie, w piątek 23 października przed południem, w Regionalnym Ośrodku Onkologicznym odbyły się konsultacje i warsztaty dla pacjentów. Oprócz informacji o rekonstrukcjach piersi pacjentki mogły zasięgnąć porady ginekologa, mieć wykonaną mammografię, USG i cytologię. Zainteresowaniem cieszyły się porady udzielane przez Annę Walczyk dotyczące specjalistycznej bielizny używanej po zabiegach rekonstrukcji piersi. Odbyły się również warsztaty psychologiczne „Przez wizualizację do zmiany”. Swoje stoisko miał także łódzki odział NFZ, gdzie uczestniczki spotkania mogły założyć konto ZIP i otrzymać informację na temat bezpłatnego leczenia.

Obchodom BRA Day towarzyszyło uroczyste otwarcie nowo wyremontowanej Poradni Onkologicznej.

Wieczorem odbyła się uroczysta gala „BRA-vissime” w auli Akademii Sztuk Pięknych im. Wł. Strzemińskiego w Łodzi. Wchodząc na uroczystość, goście mogli obejrzeć zdjęcia z sesji fotograficznej pacjentek po mastektomii i rekonstrukcji piersi leczonych w Ośrodku Onkologicznym wŁodzi. Na wielkoformatowych zdjęciach wykonanych we wnętrzach Pałacu Herbsta prezentowały się piękne kobiety ubrane w eleganckie suknie. Punktualnie o 19.00 Piotr Rogósz, łódzki dziennikarz radiowy i popularny konferansjer, zaprosił gości na salę. Ponad 400 gości szczelnie wypełniło audytorium. Otwarcie gali powierzono Jej Magnificencji prof. Jolancie Rudzkiej-Habisiak, rektor ASP w Łodzi, mgr. Wojciechowi Szrajberowi, dyrektorowi WSS im. Kopernika w Łodzi oraz założycielowi Fundacji „Pełną Piersią", piszącemu to sprawozdanie dr. Piotrowi Plucie.

Po przywitaniu zaproszonych gości dr Piotr Pluta rozpoczął galę wykładem „TOP TEN" o rekonstrukcjach piersi, krótko przedstawiając „,ranking" najważniejszych wiadomości będących tematem obchodów.

Następny wykład, pt.,,Kobiece piersi a Wielka Sztuka”, był oparty na dwugłosie "medyczno-artystycznym”. Analizując obrazy i rzeźby znanych artystów, doc. Agnieszka Kołacińska zwracała uwagę na problematykę chorób piersi, a towarzysząca jej mgr Agata Materowicz uzupełniała to spojrzenie okiem historyka sztuki.

Kluczowym wydarzeniem gali były pokazy mody takich firm jak La Mania, Moove, MMC i Alles. W role modelek wcieliły się pacjentki Ośrodka Onkologicznego w Łodzi, które przeszły mastektomię i rekonstrukcję piersi. Doskonałe przygotowanie sceniczne z profesjonalną oprawą dźwiękowo-świetlną pozwoliło na stworzenie atmosfery prawdziwych pokazów mody. Nasze modelki nie bały się zaprezentować zarówno w strojach wieczorowych, jak i w zmysłowej bieliźnie. Dla wszystkich gości była to bez wątpienia najbardziej poruszająca część gali. 


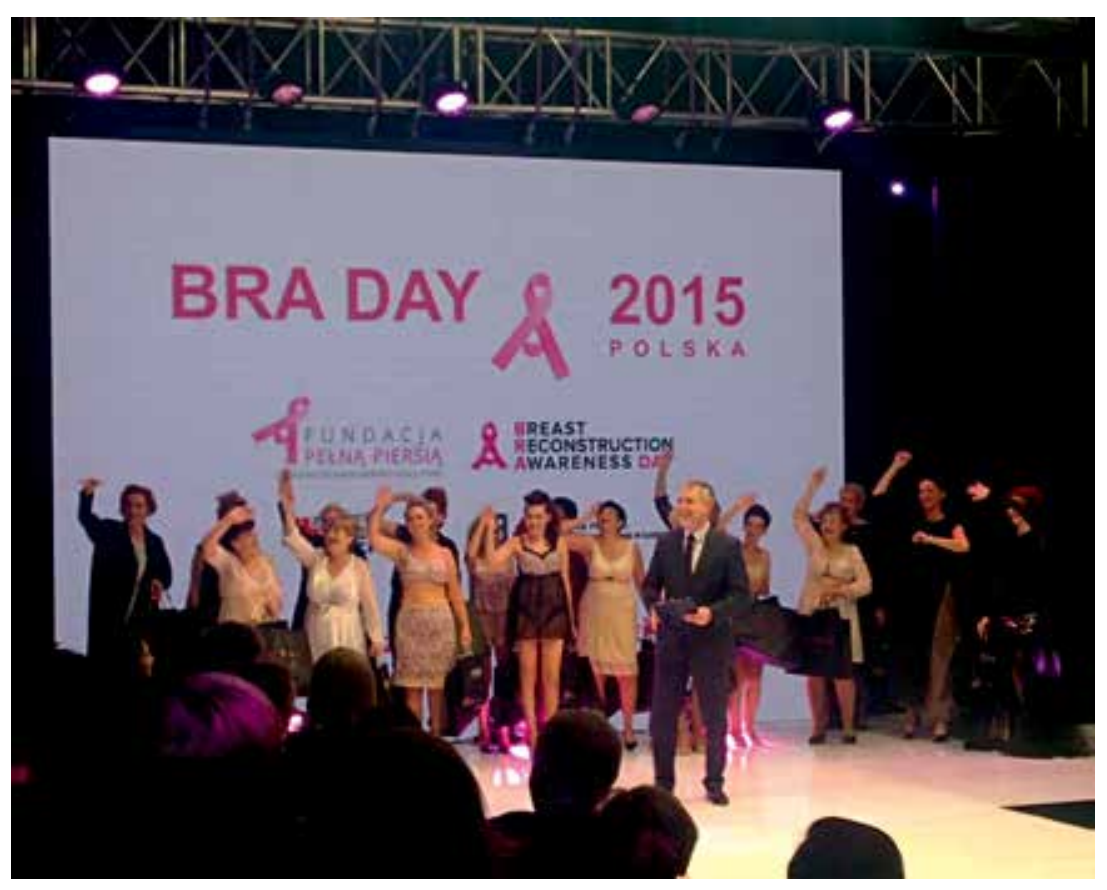

Pokaz mody na gali „BRA-vissime”. W roli modelek — pacjentki po rekonstrukcji piersi

Na niejednej twarzy pojawiła się łza wzruszenia. Brawom nie było końca.

Gala dała również możliwość zebrania środków wspierających rozwój rekonstrukcji piersi w Łodzi poprzez aukcję na rzecz Fundacji „Pełną Piersią". Prowadząca aukcję prezes Fundacji z wdziękiem i skutecznością zachęcała zebranych gości do hojności. Dzięki temu akcja BRA Day może być prowadzona przez cały rok, poprzez m.in. przygotowywanie materiałów informacyjnych dla pacjentek, pomoc w zakupie specjalistycznych staników czy szkolenie personelu medycznego w zakresie rekonstrukcji piersi.

Galę zakończył występ łódzkiej grupy Blue Cafe. W akustycznej aranżacji utwory śpiewane przez Dominikę Gawędę doskonale wpisały się w tegoroczny charakter gali. Obchody "Dnia Informacji o Rekonstrukcjach Piersi" w Łodzi w roku 2015 odbyły się pod znakiem radości, piękna i afirmacji życia.

Dzięki udziałowi i wsparciu przedstawicieli łódzkich mediów informacje o przygotowanych obchodach i relacje z ich przebiegu mogły dotrzeć do wielu mieszkańców naszego regionu i być dostępne przez cały rok na stronach internetowych. Dla uczestników akcji, pacjentek, gości i organizatorów to nie tylko miła pamiątka. Najważniejsze, aby rekonstrukcje piersi stały się rzeczywistym elementem wielospecjalistycznego leczenia chorych na raka piersi.

W imieniu organizatorów:

\section{Dr n. med. Piotr Pluta}

Klinika Chirurgii Onkologicznej

II Odział Chirurgii Onkologicznej, WSS im. M. Kopernika w Łodzi

ul. Pabianicka 62, 93-513 Łódź

e-mail:piotr.pluta@umed.lodz.pl 